\title{
A Study on Customer Attitude towards Smartphones with Special References to Ooty, The Nilgiris District
}

\author{
A. Sivaprakash ${ }^{1}$, Dr. G. Chandrasekaran ${ }^{2}$ \\ ${ }^{1}$ Ph.D Scholar, Department of Commerce, Chickkana Government Arts College, Tirpur. Tamilnadu, India \\ ${ }^{2}$ Assistant Professor, Department of Commerce, Chickkana Government Arts College, Tirpur. Tamilnadu, India
}

\begin{abstract}
Recent developments in mobile technologies have produced a new kind of device, a programmable mobile phone, the smart phone. Generally, smart phone users can program any application which is customized for needs. Furthermore, they can share these applications in online market. Therefore, smart phone and its application are now most popular keywords in mobile technology. Today"s smart phone application markets host an ever increasing number of applications. The sheer number of applications makes their review a daunting task. Apps Playground integrates multiple components comprising different detection and an automatic exploration technique for this purpose. Our evaluation shows that Apps Playground is quite effective at automatically detecting privacy leaks and malicious functionality in applications. The purpose of this paper is to present the result of a survey on the attitude and behavior of consumers toward the various types of smart phone usages such as application software, e-mail, Internet browsing, ringtones, and other mobile contents The data were collected through survey questionnaires filled by 150 individual users across the city in Ooty.
\end{abstract}

Keywords: Smart phone, Consumer behaviors, Consumer usage survey

\section{Introduction}

Most of the mobile phones nowadays are addressed as "smart phone", as they offer more advanced computing power and connectivity than a contemporary mobile phone. Literately, a smart phone is a handheld computer, as it is powerful enough to deliver various functionalities comparable to a computer. The releases of dual-core processors smart phone recently have further reaffirmed this assertion. Along with the smart phone fundamental capabilities to make voice call, video call, SMS, and MMS, smart phones have been repositioned as a "new information medium". In other words, smart phones have extended list of information processing functionalities such as managing personal time schedule, accessing Internet contents, editing documents, utilizing location- awareness function, and many other exciting applications. All these functionalities are delivered through the software installed on the smart phone. It is stressing that the ever increasing importance of mobile software and other mobile contents are solicited by the prevalent of smart phone.

\section{Objectives}

- To identify the customer attitude towards smart phone.

- To analyze the usage of features, software, and applications of Smart phone.

- To know the customer satisfaction of the smart phones.

\section{Scope of the Study}

- The study helps us to know about the student"s attitude towards smart phones.

- The study will find customers opinion about smart phone

\section{Limitation of Study}

- The study is limited to Ooty.

- It's only study about the customer's attitude towards smart phone

- The data collected from the samples may not be completely appropriate.

\section{Research Methodology}

\subsection{Research Design}

The research design of the project is descriptive as it describes data and characteristics associated with the population using mobile phones. Descriptive research is used to obtain information concerning the current status of the phenomena to describe "what exists" with respect to variables in a given situation. ${ }^{[1][2]}$

\subsection{Area of Study}

The study was conducted in Coimbatore city.

\subsection{Period of Study}

The study covers a period of 2 months.

\subsection{Method of Data Collection}

To accomplish the objectives of the study, both primary and secondary data's were collected. Primary Data Primary data is that data which is collected for the first time. It is original in nature in the shape of raw material for the purpose of collection of primary data a well structured questionnaire was filled by the respondents. The questionnaire comprises of close ended as well as ended questions. Secondary Data Secondary data is the data which is already collected by 


\section{International Journal of Science and Research (IJSR) \\ ISSN (Online): 2319-7064}

Index Copernicus Value (2013): 6.14 | Impact Factor (2014): 5.611

someone. They are secondary in nature and area in shape of finished product. Secondary data was collected so as to have accurate results. Required data was collected from various books, magazines, journals and internet.

\subsection{Sampling Method}

The sampling used for the study is convenient sampling. This sampling is selected by the researcher for the purpose of convenience to access

\subsection{Sample Size}

For the study, sample sizes of 150 respondents were selected.

\section{Research Tools for the Study}

The statistical tools used for the analysis are

- Simple percentage Analysis

- Chi square analysis

\section{Data Analysis and Interpretation}

\subsection{Chi - Square Test}

Hypothesis: Ho: There is no relationship between the Gender and Factors motivated. H1: There is relationship between the Gender and Factors motivated.

\begin{tabular}{|lc|}
\hline Chi-Square Tests & Value df Asymp. Sig. (2-sided) \\
\hline Pearson Chi-Square & 1.839 a 4.765 \\
\hline Likelihood Ratio & 1.8784 .758 \\
\hline Linear-by-Linear Association & 2741.601 \\
\hline
\end{tabular}

\section{N of Valid Cases 50 a. 5 cells $(50.0 \%)$ have expected} count less than 5. The minimum expected count is 3.36 .

Interpretation: Since $1.883<9.488$ we accept the Ho (Null Hypothesis). There is no relationship between the Gender and Factors motivated.

\subsection{Satisfaction Level of Respondent}

\begin{tabular}{|l|c|c|}
\hline Particulars & Frequency & Percentage \\
\hline Strongly Agree & 24 & 48 \\
\hline Agree & 32 & 64 \\
\hline Neutral & 36 & 72 \\
\hline Disagree & 18 & 36 \\
\hline Strongly Disagree & 14 & 28 \\
\hline Total & 100 & 200 \\
\hline Average & 50 & 100 \\
\hline
\end{tabular}

Interpretation: The above table shows that, from the respondents of 100 that $48 \%$ of the Respondents are preferred Strongly Agree, 64\% of the Respondents are preferred agree, $72 \%$ of the Respondents are preferred neutral, $36 \%$ of the Respondents are preferred disagree, and $28 \%$ of the Respondents are preferred strongly disagree.

\section{Suggestions \& Findings}

\subsection{Suggestions}

From the result inferred by the data collected and little secondary information the following suggestions are given to improve consumer buying behavior. To explore the market, mobile industry have to concentrate more on youth segment by giving more advanced $\neg$ features. Compared to urban and suburban the mobile phone usage in rural is low so the mobile companies have to go for campaigns to create awareness among the rural people.

\subsection{Findings}

Majority of the respondents (29\%) are male Majority of the respondents $(25 \%)$ are having satisfaction (neutral)

\section{Conclusion}

The consumer buying a variety of smart phones which satisfy his wants and they are always influenced by his purchasing activities by some considerations which lead him to select a particular brand or a particular operating systems in preferred to others. Consumers mostly preferred Samsung smart phones. From this study I have gained lot of practical exposure about consumer buying behavior towards smart phones.

\section{References}

[1] Howard Rheingold "smart mobs" the next social revolution Himanshu Dwivedi "Mobile Application Security" Edition 1,2010

[2] C.R Kothari (1990), Research Methodology, Second revised edition, New Age international (P) Limited, Publishers, New Delhi 